Diabetologia (1992) 35: 77-79

\title{
Hypomagnesaemia in Type 2 (non-insulin-dependent) diabetes mellitus is not corrected by improvement of long-term metabolic control
}

\author{
Ch.Schnack ${ }^{1}$, I. Bauer ${ }^{1}$, P.Pregant ${ }^{1}$, P. Hopmeier ${ }^{2}$ and G. Schernthaner $^{1}$ \\ ${ }^{1}$ Department of Medicine I and ${ }^{2}$ Institute of Clinical Chemistry, Rudolfstiftung Hospital, Vienna, Austria
}

\begin{abstract}
Summary. Low levels of magnesium have frequently been reported in diabetes mellitus especially in poorly controlled Type 1 (insulin-dependent) diabetic patients. Furthermore hypomagnesaemia might contribute to insulin resistance in Type 2 (non-insulin-dependent) diabetes. As the influence of improved metabolic control on plasma magnesium levels is unknown in Type 2 diabetic patients we studied magnesium plasma levels in 50 patients 1) before, 2) one and 3) three months after the initiation of insulin therapy or intensified treatment with oral hypoglycaemic agents. Magnesium plasma levels were measured by a colorimetric method and were significantly reduced in diabetic patients compared to healthy control subjects $(0.79 \pm 0.01 \mathrm{mmol} / 1$ vs $0.88 \pm 0.01$ $\mathrm{mmol} / \mathrm{l} ; p<0.0001)$. Metabolic control was significantly improved as documented by reduced $\mathrm{HbA}_{1 \mathrm{C}}$ levels in both in-
\end{abstract}

sulin-treated patients or the patients on oral hypoglycaemic agents $(p<0.003)$. However, plasma magnesium levels remained unchanged during the follow-up in the insulintreated group (1: $0.79 \pm 0.02 \mathrm{mmol} / \mathrm{l} ; 2: 0.81 \pm 0.02 \mathrm{mmol} / \mathrm{l}$; 3: $0.79 \pm 0.01 \mathrm{mmol} / 1)$ as well as in the patients on oral hypoglycaemic agents $(1: 0.79 \pm 0.03 \mathrm{mmol} / 1 ; 2: 0.78 \pm 0.02 \mathrm{mmol} /$ l; $3: 0.84 \pm 0.04 \mathrm{mmol} / \mathrm{l})$. This study shows that even marked improvement of glycaemic control does not correct hypomagnesaemia in Type 2 diabetes. We conclude that hypomagnesaemia might be related to the insulin-resistant state and that possible beneficial effect of chronic magnesium administration should be evaluated in these patients.

Key words: Diabetes mellitus, Type 2 (non-insulin-dependent) diabetes, insulin resistance, magnesium, electrolytes.
Reduced magnesium plasma levels have frequently been reported in both Type 1 (insulin-dependent) and Type 2 (non-insulin-dependent) diabetic patients [1-5]. An inverse relationship between metabolic control and plasma magnesium levels was found in Type 1 diabetic patients and has been attributed to increased urinary magnesium losses [2,3]. In Type 2 diabetic patients however, hypomagnesaemia can be both a consequence or a cause of increased insulin resistance [5]. The fact, that chronic magnesium supplements in Type 2 diabetic patients improves both islet Beta-cell response and insulin action $[6,7] \mathrm{fa}-$ vours the hypothesis that hypomagnesaemia is closely related to insulin resistance in these patients. It has been suggested that Type 2 diabetic patients may benefit from chronic therapeutic administration of magnesium salt $[6,7]$. On the other hand it is not known whether improvement of metabolic control per se and/or insulin therapy corrects hypomagnesaemia in these patients. We therefore studied the influence of improved diabetes control with either (a) initiation of insulin substitution or (b) intensified treatment with strict diet and oral hypoglycaemic agents on plasma magnesium levels in
50 Type 2 diabetic patients with insufficient glycaemic control.

\section{Subjects and methods}

The study was performed in 50 Type 2 diabetic patients $(21$ males and 29 females; age $61 \pm 11$ years, diabetes duration $11 \pm 8$ years, $\mathrm{HbA}_{1 \mathrm{C}} 10.5 \pm 1.8$ relative $\%$; mean $\pm \mathrm{SD}$ ) with insufficient metabolic control on oral hypoglycaemic agents (OHA). Patients were hospitalized and took part in the diabetes education programme of our unit. In 35 patients insulin treatment was started, whereas in 15 patients good metabolic control was achieved by continuation of OHA treatment due to maximal dietary efforts. None of the patients had marked renal damage or had taken magnesium drugs or hypotensive diuretics. The diet was kept constant throughout the whole study period (treatment of hypoglycaemic attacks excluded), noncompliant subjects were excluded. The control group consisted of 50 healthy subjects matched for age and sex.

Blood samples were taken the morning after overnight fasting and were repeated one month and three months after the start of medical treatment in the clinic outpatient department. Magnesium was measured by a colorimetric method (Xylidyl blue reaction) using an automated analysis system (13 M Hitachi 717 Naka works 
Table 1. The influence of insulin therapy or intensified treatment with oral hypoglycaemic agents (OHA) on fasting blood glucose and serum lipid levels in Type 2 (non-insulin-dependent) diabetic patients. Data before treatment (1) compared to one (2) and three months (3) after start of therapy

\begin{tabular}{|c|c|c|c|c|c|c|}
\hline & \multicolumn{3}{|c|}{ Insulin treatment } & \multicolumn{3}{|c|}{ OHA treatment } \\
\hline & $\overline{1}$ & 2 & 3 & 1 & 2 & 3 \\
\hline $\begin{array}{l}\text { Fasting blood } \\
\text { glucose }(\mathrm{mmol} / \mathrm{l})\end{array}$ & $15 \pm 0.83^{\mathrm{d}}$ & $10.5 \pm 0.55^{\mathrm{d}}$ & $10.3 \pm 0.55^{\mathrm{d}}$ & $13 \pm 1.22^{\mathrm{a}}$ & $10.2 \pm 0.6^{\mathrm{a}}$ & $9.8 \pm 0.7^{\mathrm{a}}$ \\
\hline $\begin{array}{l}\text { Triglycerides } \\
(\mathrm{mmol} / \mathrm{l})\end{array}$ & $3.0 \pm 0.4^{b}$ & $1.8 \pm 0.17^{\mathrm{b}}$ & $1.6 \pm 0.18^{b}$ & $2.7 \pm 0.5$ & $2.4 \pm 0.4$ & $2.4 \pm 0.4$ \\
\hline $\begin{array}{l}\text { Cholesterol } \\
(\mathrm{mmol} / \mathrm{l})\end{array}$ & $6.7 \pm 0.39$ & $6.5 \pm 0.28$ & $6.3 \pm 0.23$ & $6.4 \pm 0.44$ & $6.2 \pm 0.5$ & $6.6 \pm 0.44$ \\
\hline $\begin{array}{l}\text { HDL cholesterol } \\
(\mathrm{mmol} / 1)\end{array}$ & $1.17 \pm 0.08^{c}$ & $1.48 \pm 0.08^{\circ}$ & $1.53 \pm 0.08^{c}$ & $1.24 \pm 0.08$ & $1.24 \pm 0.08$ & $1.4 \pm 0.08$ \\
\hline $\begin{array}{l}\text { LDL cholesterol } \\
(\mathrm{mmol} / \mathrm{l})\end{array}$ & $3.9 \pm 0.49$ & $3.9 \pm 0.13$ & $4.0 \pm 0.2$ & $3.7 \pm 0.28$ & $3.5 \pm 0.26$ & $4.0 \pm 0.28$ \\
\hline
\end{tabular}

Values are means \pm SEM

${ }^{\mathrm{a}} p<0.025$ ( 1 vs 2,1 vs 3,2 vs 3$) ;{ }^{\mathrm{b}} p<0.0005$ ( 1 vs 2,1 vs 3$) ;{ }^{\mathrm{c}} p<0.005\left(1\right.$ vs 2,1 vs 3 ); ${ }^{\mathrm{d}} p<0.0001$ ( 1 vs 2,1 vs 3$)$

limited, Tokyo, Japan). The correlation coefficient between the colorimetric method of our laboratory and the Atomic Absorption Spectrophotometry was $r=0.97$ ( $p<0.0001)$. Blood glucose, lipids and routine clinical parameters were determined by a parallel analyser. $\mathrm{HbA}_{1 \mathrm{C}}$ was measured by HPLC.

\section{Statistical analysis}

Statistical analysis was performed using the analysis of variance procedure with correction for multiple measurements using the SAS program. Data are expressed as means \pm SEM unless otherwise stated.
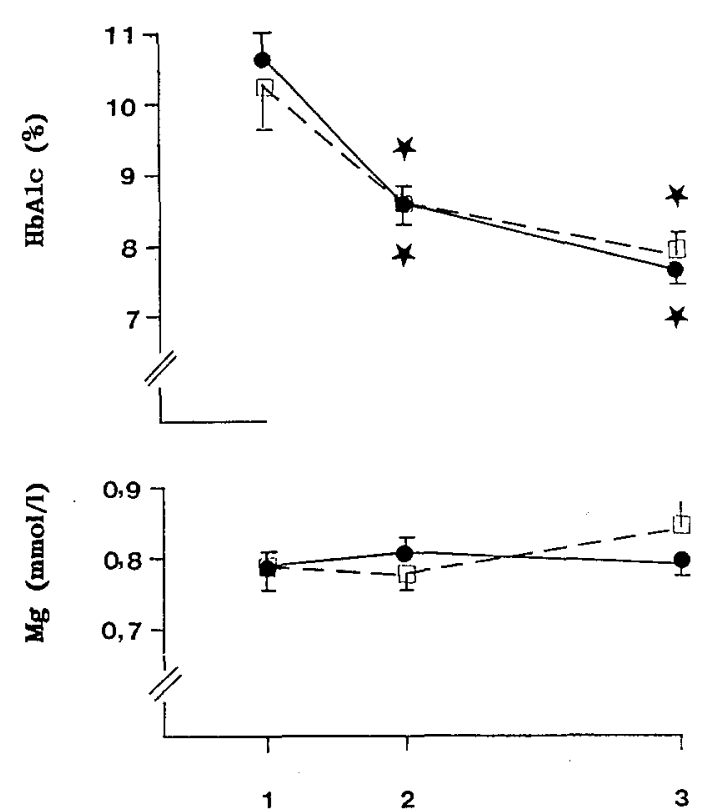

Fig.1. The effects of improvement of metabolic control by either insulin (-) or intensified treatment with strict diet and oral hypoglycaemic agents $(\square)$ on $\mathrm{HbA}_{1 \mathrm{C}}$ and plasma magnesium (Mg) levels. Ordinate: upper curve: $\mathrm{HbA}_{1 \mathrm{C}}$ concentration (relative \%, means \pm SEM), lower curve: plasma magnesium levels (mmol/l, means \pm SEM). Abscissa: Time before (1), and one (2) and three (3) months after start of treatment. $\star, p<0.0003$ vs 1 (before treatment)

\section{Results}

Plasma magnesium levels were significantly reduced in the Type 2 diabetic patients compared to healthy control subjects $(0.79 \pm 0.01 \mathrm{mmol} / 1$ vs $0.88 \pm 0.01 \mathrm{mmol} / \mathrm{l}$; $p<0.0001$ ).

The effects of improvement of metabolic control on blood glucose and serum lipids in the Type 2 diabetic patients are shown in Table 1. In both the insulin-treated group and the group treated with OHA a marked reduction of fasting blood glucose concentration was found; changes in serum lipid levels, namely the reduction of serum triglycerides and the increase in HDL cholesterol levels were only significant in the insulin-treated patients.

As demonstrated in Figure 1 we observed a marked reduction of $\mathrm{HbA}_{1 \mathrm{C}}$ values by medical intervention in both the insulin-treated group and the patients on OHA. Plasma magnesium levels, however, remained unchanged during the follow-up in the insulin-treated group as well as in the patients on OHA (Fig.1).

Furthermore, no significant correlations between degree of metabolic control ( $\mathrm{HbA}_{1 \mathrm{C}}$, blood glucose) and plasma magnesium levels were found.

\section{Discussion}

The main finding of the present study is, that plasma magnesium levels are significantly reduced in Type 2 diabetic patients and are not influenced by improvement of metabolic control.

As reported previously [8] we found no correlation between the $\mathrm{HbA}_{1 \mathrm{C}}$ and fasting blood glucose concentrations and plasma magnesium levels in Type 2 diabetic patients, whereas in Type 1 diabetic patients a correlation between the fasting blood glucose and serum magnesium was observed [8]. These results indicate that in contrast to Type 1 diabetic patients $[2,4,10]$ hypomagnesaemia in Type 2 diabetic patients is not directly correlated to metabolic control. 
We have further shown that even marked improvement of metabolic control as documented by a significant reduction of $\mathrm{HbA}_{1 \mathrm{C}}$ and fasting blood glucose levels has no effect on the reduced plasma magnesium levels in Type 2 diabetes, in spite of whether patients receive insulin therapy or intensified treatment with strict diet and OHA.

In fact, it was recently shown, that hypomagnesaemia not only occurs in Type 2 diabetic patients $[1,4,5,8]$ but also in patients with essential hypertension $[9,11]$. Furthermore, Type 2 diabetes, aging and essential hypertention [5, 10-12], classic conditions associated with insulin resistance are associated with an impaired insulin mediated accumulation of magnesium into erythrocytes $[9,13]$. In vitro it was shown, that even high levels of insulin cannot correct the reduced magnesium shift into erythrocytes from insulin-resistant Type 2 diabetic patients with hypomagnesaemia, which might be explained by a post-receptor defect [5].

In diabetic patients hypomagnesaemia might represent an independent risk factor for cardiovascular complications $[14,15]$. Recently it was shown, that chronic magnesium administration might improve the insulin response and insulin action in insulin-resistant Type 2 diabetic patients $[6,7]$.

Recently [16] chronic magnesium supplementation has been discussed as a possible beneficial therapeutic approach increasing both insulin secretion and insulin sensitivity in Type 2 diabetic patients. Since hypomagnesaemia persists even after marked improvement of glycaemic control the effects of magnesium administration should be evaluated in Type 2 diabetic patients in long-term studies.

Acknowledgements. This study was made possible by the expert assistance of A.Bergen and K. Meyer. The secretarial assistance of S. Singer and G.Harringer is also gratefully acknowledged. Financial support for this study was provided by the "Jubiläumsfond der Österreichischen Nationalbank", project No 3434.

\section{References}

1. Mather HM, Nisbet JA, Burton GH et al. (1979) Hypomagnesaemia in diabetes. Clin Chim Acta 95: 235-242

2. McNair P, Christensen MS, Christiansen C, Modshod S, Transbol IB (1982) Renal hypomagnesaemia in human diabetes mellitus: its relation to glucose homeostasis. Eur J Clin Invest 12: 81-85
3. Ponder SW, Brouhard BH, Travis LB (1990) Hyperphosphaturia and hypermagnesuria in children with IDDM. Diab Care 13: $437-441$

4. Sjögren A, Floren CH, Nilsson A (1988) Magnesium potassium and zinc deficiency in subjects with type I and type II diabetes. Acta Med Scand 224: 461-465

5. Paolisso G, Sgambato S, Giugliano D et al. (1988) Impaired insulin-induced erythrocyte magnesium accumulation is correlated to impaired insulin-mediated glucose disposal in Type-2 (non-insulin-dependent) diabetic patients. Diabetologia 31:910915

6. Paolisso G, Passariello N, Pizza G et al. (1989) Dietary magnesium supplements improve B-cell response to glucose and arginine in elderly non-insulin dependent diabetic subjects. Acta Endocrinol 121: 16-20

7. Paolisso G, Sgambato S, Pizza G, Passariello N, Varricchio M, D'Onofrio $F$ (1989) Improved insulin response and action by chronic magnesium administration in aged NIDDM subjects. Diab Care 12:265-269

8. Prager R, Schernthaner G, Kostner G, Mühlhauser I, Meisinger V (1982) Hypomagnesiämie bei Diabetes mellitus. Korrelationsanalysen mit Stoffwechselkontrollgrad, Lipidstatus und Thrombozytenfunktion. Akt Endokrin Stoffw 3: 140-143

9. Paolisso G, Passariello N, Sgambato S et al. (1987) Impaired insulin-mediated erythrocyte magnesium accumulation in essential hypertension. Clin Sci 73: 535-539

10. Fink RI, Kolterman OG, Griffin J, Olefsky JM (1983) Mechanisms of insulin resistance in aging. J Clin Invest 71: 1523-1535

11. Rowe JW, Minaker KL, Pallotta JA, Flier JS (1983) Characteristics of the insulin resistance of aging. J Clin Invest 71: 15811587

12. Ferrannini E, Buzzigoli G, Bonadonna R et al. (1987) Insulin resistance in essential hypertension. N Engl J Med 317: 350-357

13. Paolisso G, Sacchettino A, Sgambato S, Gentile S, Varicchio M, D'Onofrio $F$ (1988) Impaired insulin-mediated erythrocyte magnesium accumulation in the elderly. Diab Nutr Metab 1:215-219

14. Seelig MS, Heggtveit HA (1974) Magnesium interrelationship in ischemic heart disease: a review. Am J Clin Nutr 27:59-79

15. Mather HM, Levin GE, Nisbet JA (1982) Hypomagnesaemia and ischemic heart disease in diabetes. Diab Care 5: 452-463

16. Paolisso G, Scheen A. D'Onofrio F, Lefèbvre P (1990) Magnesium and glucose homeostasis. Diabetologia 33:511-514

Received: 11 July 1991

and in revised form: 19 September 1991

Prof. G.Schernthaner

Department of Medicine I

Rudolfstiftung Hospital Vienna

Juchgasse 25

A-1030 Vienna

Austria 